\title{
Anaerobically fermented colostrum: an alternative for feeding calves
}

\author{
Colostro fermentado anaerobicamente: uma alternativa para alimentação de bezerras
}

\author{
Mara Helena Saalfeld ${ }^{I}$ Daniela Isabel Brayer PereiraII Kathleen Rodrigues Krüger Silveira' \\ Renata Schramm ${ }^{\text {II }}$ Júlia de Souza Silveira Valente ${ }^{\mathrm{II}}$ Jéssica Lopes Borchardt ${ }^{\mathrm{II}}$ \\ Márcia Arocha Gularte ${ }^{\mathrm{II}}$ Fábio Pereira Leivas Leite ${ }^{\mathrm{II}^{*}}$
}

\section{ABSTRACT}

Milk or commercial milk replacer blends are the most expensive components in final costs of calves breeding. Colostrum is available and it is the appropriate sources for calves' nutrition, being an excellent option as milk substitute. Besides having both nutritional and immunological characteristics that are superior to milk, colostrum represents no costs to the producer. However, difficulties in preservation of colostrum generate controversy results. The aim of this study was to evaluate the anaerobically fermented colostrum (colostrum silage) as liquid diet for dairy calves. We evaluated the microbiological and physicochemical properties of silage, and performance of 31 animals up to 60 days age. From 21 days until 360 days of fermentation we isolated only bacteria of the genus Lactobacillus spp. The physicochemical evaluation of colostrum silage revealed a tendency to maintain the protein, dry matter and fat values during the evaluation period. The average weight gain of calves fed with milk was $0.6 \mathrm{~kg}_{\text {day }}^{-1}$ for female and $0.6 \mathrm{~g} \mathrm{day}^{1}$ for males while those fed with colostrum silage was significantly higher $(P<0.05)$ with a mean of $0.7 \mathrm{~kg} \mathrm{day}^{-1}$ for female and $0.7 \mathrm{~kg} \mathrm{day}^{-1}$ for males. The results of this study demonstrated that colostrum silage keeps the properties necessary for the development of the calves and is a suitable replacement for calves', milk.

Key words: colostrum silage, Lactobacillus spp., calves nutrition.

\section{RESUMO}

O leite ou substitutos comerciais do leite são os componentes mais caros do custo final da criação de bezerras. O colostro é uma fonte adequadada de nutrientes, sendo uma excelente opção como substituto do leite. Além de ter características nutricionais e imunológicas superiores ao leite, o colostro não representa custos para o produtor. No entanto, as dificuldades de preservação do colostro têm gerado resultados controversos. O objetivo deste estudo foi avaliar o colostro fermentado anaerobicamente (silagem de colostro) como dieta líquida para bezerras leiteiras. Foram avaliadas as propriedades microbiológicas e físico-químicas da silagem de colostro e o desempenho de 31 animais até 60 dias de idade. A partir de 21 dias até 360 dias de fermentação, foram isoladas apenas bactérias do género Lactobacillus spp. A avaliação físico-química da silagem de colostro revelou uma tendência para manter os valores de proteína, gordura e matéria seca durante o período de avaliação. O ganho médio de peso dos bezerros alimentados com leite foi de $0,6 \mathrm{~kg} \mathrm{dia}^{-1}$ para as fêmeas e de $0.6 \mathrm{~kg} \mathrm{dia}^{-1}$ para os machos, enquanto que o ganho médio de peso para os animais alimentados com silagem colostro foi significativamente maior $(P<0,05)$, com média de $0,7 \mathrm{~kg} \mathrm{dia}^{-1}$ para as fêmeas e $0,7 \mathrm{~kg}$ dia $^{-1}$ para os machos. Os resultados deste estudo mostram que a silagem de colostro mantém as propriedades necessárias para o desenvolvimento dos animais, sendo um substituto adequado para o leite.

Palavras-chave: silagem de colostro, Lactobacillus spp., nutrição, bezerros.

\section{INTRODUCTION}

Colostrum is considered fundamental to calf development, not only as food but also transmitting passive immunity (GEORGIEV, 2008; GODDEN, 2009). In the management of dairy cattle, calves receive colostrum during the first four days of life, and then colostrum is replaced by milk (LUCCI, 1989). However, milk is the farmers' product, thus feeding calves with milk has an economic impact in his income. In most cases, milk substitutes have questionable quality, since in general have insufficient

'Emater, Associação Sulina de Crédito e Assistência Rural (ASCAR), Universidade Federal de Pelotas (UFPEL), Pelotas, RS, Brasil.

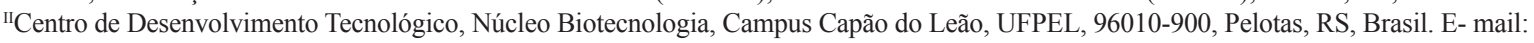
fabio@leivasleite.com.br.*Autor para correspondência.

IIIUniversidade de Santa Cruz do Sul (UNISC), Santa Cruz do Sul, RS, Brasil. 
milk protein in its formulation (DRACKLEY, 1999). The proteolytic system in cattle remains immature from birth until three weeks of age and they are unable to digest proteins other than from milk (NRC, 2001). Choice of feed administered has a significant impact on the growth, health, and profitability of the calves, and underlines the need to develop adequate milk substitutes for proper animal nutrition (DRACKLEY, 1999). Colostrum has nutritional characteristics superior to milk, and can be used as a substitute in animal feed (KEHOE et al., 2007). ALLEN in 1944 stored frozen colostrum for the calves for more than a year, with favorable results. Another alternative emerged with the use of naturally acidified colostrum (FOLEY \& OTTERBY, 1978) or colostrum acidified with propionic acid (LANUZA et al., 1980). Although the colostrum can be acidified and retain its food quality, problems have been reported such as alopecia, diarrhea, and acceptability (CAMPOS et al., 1986). Aerobically fermented colostrum has been used in many countries since the 1970s, but has fallen into subsequent disuse (NAHMS, 1993). The anaerobic fermentation was introduced as alternative to colostrum conservation by SAALFELD (2008).

Given this, our study aimed to develop and evaluate anaerobically fermented colostrum (colostrum silage) as milk substitute.

\section{MATERIAL AND METHODS}

\section{Colostrum}

Colostrum was collected by milking multiparous Holstein cows from properties in Rio Grande do Sul state, Brazil. First and second day postpartum colostrum was collected in polyethylene terephthalate bottles (PET); filled, sealed and stored for at least 21 days at room temperature for anaerobic fermentation, resulting in a product that was designated "colostrum silage".

Microbiological evaluation of colostrum and colostrum silage

Colostrum from 20 dairy cows was collected and fractionated into 20 samples of $226 \mathrm{~mL}$ each for microbiological evaluation. The fresh colostrum was analyzed immediately, and the colostrum silage was analyzed every 7 days up to 30 days, and thereafter at $60,90,120,180$ and 360 days of fermentation. A 10 fold dilution series $\left(10^{1}-10^{8}\right)$ of colostrum and colostrum silage was prepared in $1 \%$ peptone water. Aliquots of $100 \mu \mathrm{L}$ were seeded in MacConkey, Chapmann and blood (8\% sheep) agar base (Difco, USA), culture media: incubated aerobically at $37^{\circ} \mathrm{C}$ for 24 hours, and in Man, Rogosa and Sharpe (MRSBiobras, Brazil) medium: incubated microaerophilic at $37^{\circ} \mathrm{C}$ for 48 hours. The bacteria were characterized by Gram staining and biochemically to identify the genus (Catalase test, maltose fermentation, Voges Proskauer and nitrate).

Physicochemical evaluation of fresh colostrum and colostrum silage

The colostrum samples $(\mathrm{n}=10$ individual cows) were collected and analyzed in natura at calf birth, and every 12 hours up to 60 hours. After seven days milk was collected and analyzed $(n=10$ individual cows). The colostrum silage $(\mathrm{n}=20$ individual cows) was evaluated every 7 days up to 30 days, and later at 60 days of fermentation. The physicochemical assessments were performed in duplicate according to the methodology described by the Analytical Standards INSTITUTE ADOLFO LUTZ (1985). The parameters evaluated were: $\mathrm{pH}$ (measured by digital potentiometer - DM 20), acidity in (Dornic degrees), lactic acid, protein (Kjeldahl digestion, factor 6.5), dry matter (oven drying method at $105^{\circ} \mathrm{C}$ ), ash (incineration in a muffle furnace at $550^{\circ} \mathrm{C}$ ), fat (Gerber method), and lactose (Fehling's method with minor modifications, equation 1). The modifications were as follows: we used $5 \mathrm{~mL}$ for Fehling solutions A and B, to titrate colostrum silage filtrate was used in place of glucose at $1 \%$. Being a sample with high protein content we added $5 \mathrm{~mL}$ of potassium ferrocyanide at $6 \%$, and $5 \mathrm{ml}$ of zinc acetate at $12 \%$, added to the samples tested, and centrifuged for 5 minutes at $(6 \mathrm{~g})$. The resulting contents were filtered with dry filter paper and used for titration.

Equation 1:\% Lactose $=($ Final solution volume $\mathrm{x} 1.39 \mathrm{x}$ Fehling factor / spent burette volume $\mathrm{x}$ grams of sample in solution) $\mathrm{x} 100$.

Evaluation of colostrum silage as animal feed replacement

For evaluation of colostrum silage as feed replacement, we used 31 Holstein calves of both sexes, with five days of life from the same farm. In the first five days of age the animals were fed with 4.5 liters of colostrum. Group 1 ( $\mathrm{n}=17 ; 7$ female and 10 males) was fed a diet based on whole milk; Group 2 $(\mathrm{n}=14 ; 9$ female and 5 males) was fed a diet of silage based colostrums in nature, divided into twice daily. The experiment was performed from September to March. The animals were housed in mobile cabins randomly divided into two groups. The diet based in the silage was prepared as follow: After 21 days of fermentation the bottles were opened, and mixed 
with equal volumes of water, then were used as milk replacer for feeding the calves. The silage colostrum or milk, were given quantity of $4.5 \mathrm{~L}$ day $^{-1}$ divided twice daily until 14 days, after the fifteenth day to weaning animals received $3.5 \mathrm{~L} \mathrm{day}^{-1}$, once per day. The supply of water was ad libitum.

After seven days, the animals received a diet supplemented with $50 \mathrm{~g}$ day $^{-1}$ of pelleted commercial calve feed $\left(\right.$ Danby $\left.{ }^{\circledR}\right)$. The commercial feed ingredients consisting of $16 \%$ crude protein with the following composition: corn grain, sorghum grain, wheat bran, soybean meal, limestone, dicalcium phosphate, sodium chloride, and Premix. The commercial feed was doubled every five days until they receive $800 \mathrm{~g} \mathrm{day}^{-1}$, and this amount was maintained until weaning. The animals were weighed at birth, and at weaning (60 days) using tape weighing (HEINRICHS, 1987). The daily weight gain was calculated as the difference between final and initial weight (at day of birth) divided by the number of days contained in the period between the two weightings.

\section{Statistical analyses}

The variance analysis (ANOVA) was used for statistical analysis, and the averages were compared according to the test $\mathrm{T}$ at $5 \%$ significance, the program used was Statistics for Windows v. 6.0.

\section{RESULTS}

The microbiological evaluation of both fresh colostrum and colostrum silage is presented in Table 1. The presence of the bacteria Lactobacillus spp., Staphylococcus spp., Escherichia spp.; Klebsiella spp., Bacillus spp. and yeast of the genus Candida spp. was observed in colostrum and the silage for up to 14 days. From 21 days of fermentation we isolated only bacteria of the genus Lactobacillus spp.. Besides microbiological analyses, we carried out physicochemical analyses from fresh colostrum up to 60 hours postpartum. These analyses showed that there were variations in the levels of protein and dry matter during the period analyze, the other constituents remained constant (Table 2). Already the physicochemical evaluation of colostrum silage revealed a tendency to maintain the values of protein, dry matter and fat during the evaluation period. However, there was a decrease in the lactose percentage. It was observed that the $\mathrm{pH}$ values fell after seven days of fermentation, accompanied by the percentage increase in lactic acid (Table 3 ).

Evaluation of weight gain the calves receiving colostrum silage showed a significative $(\mathrm{P}<0.05)$ higher gain weight (daily and cumulative) as compared to control group (Table 4).

\section{DISCUSSION}

Colostrum has potential for use as calf feed during the suckling period, having been recommended since the early 1950's (APPLEMAN \& OWEN, 1975). Colostrum differs from milk mainly by its higher concentrations of proteins, minerals, vitamins, fats, total solids, and ash (KEHOE et al, 2007). In the present study, the chemical composition of the colostrum samples (Table 2) was in agreement to describe by KEHOE et al. (2007). It was evident that until the sixth day postpartum, colostrum has higher protein levels than those found in milk. Although the natural composition and physicochemical characteristics of colostrum are related to various aspects inherent to the animal, including race, parity, pre-partum conditions, dry duration time, postpartum time and feed used (FOLEY \& OTTERBY 1978), colostrum is nutritionally rich, and can be used in animal feed. However, the availability of colostrum, as well as its storage, and preservation are factors that hinder its use. Many studies have been conducted on the use of bovine colostrums (FOLEY \& OTTERBY, 1978), but it has fallen into disuse since the 1980's because of difficulties involving preservation (NAHMS, 1993). LANUZA et al. (1980) demonstrated the

Table 1 - Microorganisms isolated from colostrum.

\begin{tabular}{|c|c|c|c|c|c|c|c|}
\hline \multirow{2}{*}{ Microorganisms isolated } & \multirow[b]{2}{*}{ Day 0} & \multirow[b]{2}{*}{ Day 7} & \multirow[b]{2}{*}{ Day 14} & \multirow[b]{2}{*}{ Day 21s } & \multirow[b]{2}{*}{ Day 30} & \multirow[b]{2}{*}{ Day 60} & \multirow[b]{2}{*}{ Day $90-360$} \\
\hline & & & & & & & \\
\hline Lactobacillus spp. & $2 \times 10^{7}$ & $6 \times 10^{10}$ & $5.7 \times 10^{8}$ & $4.3 \times 10^{7}$ & $2.9 \times 10^{7}$ & $2.3 \times 10^{6}$ & $2.3 \times 10^{4}$ \\
\hline Escherichia spp. & $6 \times 10^{7}$ & $24 \times 10^{2}$ & ND & ND & $\mathrm{ND}$ & ND & ND \\
\hline Staphylococus spp. & $5 \times 10^{9}$ & $3 \times 10^{4}$ & ND & ND & ND & ND & ND \\
\hline Candida spp. & $1 \times 10^{1}$ & $1 \times 10^{1}$ & $1 \times 10^{1}$ & ND & ND & ND & ND \\
\hline Klebsiella spp. & $1 \times 10^{1}$ & ND & ND & ND & ND & ND & ND \\
\hline
\end{tabular}


Table 2 - Physical-chemical evaluation of colostrum and milk hours post partum.

\begin{tabular}{|c|c|c|c|c|c|c|c|}
\hline Post-partum & $\mathrm{pH}$ & Lactose $(\%)$ & $\operatorname{Ash}(\%)$ & $\begin{array}{l}\text { Protein }(\%) \\
\text { Média (SD) }\end{array}$ & Fat $(\%)$ & DM (\%) & ${ }^{\circ} \mathrm{D}$ \\
\hline $0 \mathrm{~h}$ & $6.4(0.24)$ & $2.6(0.44)$ & $1.7(0.92)$ & $16.6(3.57)$ & $6.0(0.90)$ & $26.0(4.48)$ & $30(9.25)$ \\
\hline $12 \mathrm{~h}$ & $6.2(0.33)$ & $2.7(0.53)$ & $1.6(0.67)$ & $16.1(3.83)$ & $5.6(0.28)$ & $19.6(5.7)$ & $28(12.25)$ \\
\hline $24 \mathrm{~h}$ & $6.2(0.13)$ & $3.2(0.60)$ & $1.2(0.028)$ & $10.4(3.73)$ & $6.4(0.63)$ & $14.7(0.91)$ & $35(5.5)$ \\
\hline $36 \mathrm{~h}$ & $6.4(0.20)$ & $3.1(0.51)$ & $1.4(0.23)$ & $9.5(3.15)$ & $5.9(0.50)$ & $15.3(0.81)$ & 25. (4.40) \\
\hline $48 \mathrm{~h}$ & $6.3(0.08)$ & $3.2(0.42)$ & $1.2(0.08)$ & $7.0(1.44)$ & $6.0(0.52)$ & $15.5(1.40)$ & $46(3.53)$ \\
\hline $60 \mathrm{~h}$ & $6.3(0.09)$ & $3.4(0.31)$ & $1.2(0.10)$ & $6.9(1.07)$ & $5.9(0.36)$ & $14.1(0.05)$ & $25(4.76)$ \\
\hline Milk & $6.6(0.08)$ & $4.5(0.21)$ & $0.6(0.09)$ & $3.1(0.18)$ & $3.7(0.61)$ & $12.6(0.98)$ & $18(0.06)$ \\
\hline
\end{tabular}

$\mathrm{DM}=$ dry matter; ${ }^{\circ} \mathrm{D}=$ Degrees Dornic $;(\mathrm{SD})=$ standard deviation

impossibility of preserving the acidified colostrum in temperatures above $30^{\circ} \mathrm{C}$. Nevertheless, we observed that maintenance of colostrum silage in temperatures above $30^{\circ} \mathrm{C}$ show no changes in its proprieties (data not shown). STEWART et al. (2005) reported that pathogenic bacteria such as Mycobacterium avium, Salmonella spp., Listeria monocytogenes and Escherichia coli can be transmitted by the colostrum. In this work we found that colostrum samples that had been initially detected with bacteria (Table 1), was not isolated after anaerobic fermentation. We observed that the microorganisms which remained viable up to 360 days were bacteria of the genus Lactobacillus spp., suggesting that this is the microorganism responsible for fermentation. Bacteria of this genus make up the important group of lactic acid bacteria which are used as probiotics in foods for both humans and animals. The majority of pathogenic bacteria do not survive acidic conditions (HIRSH, 2003). We can suggest that one of the factors that might contribute with the growth control of the microbial during the silage was the decrease of $\mathrm{pH}$. Also, the presence of Lactobacillus spp. in fermented products acts by suppressing both the growth of spoilage microorganisms, as well as potentially pathogenic bacteria (BURITI \& SAAD 2007). The physicochemical analyses showed that the colostrum silage retained the characteristics necessary to meet the nutritional needs of the developing animal. The results of this study showed that even after 60 days of fermentation, colostrum tends to maintain the initial values of protein, dry matter, fat, minerals and a $\mathrm{pH}$ drop to 4.0. The elevation of lactic acid probably occurred due to Lactobacillus spp. metabolism of lactose, which after 60 days of fermentation was no longer detected. Although HAGA et al. (2008) have reported that lactose is the main energy source for pre-ruminants, in this work we infer that the fat and lactic acid present in the silage are sufficient to provide energy for animal growth. This was evident in the weight gain of the animals fed with colostrum silage which was higher than the recommended by NRC (2001). The average weight gain of calves fed with milk was $0.6 \mathrm{~kg} \mathrm{day}^{-1}$ for female and $0.6 \mathrm{~kg} \mathrm{day}^{-1}$ for males while those fed with colostrum silage was significantly higher $(\mathrm{P}<0.05)$ with a mean of $0.7 \mathrm{~kg}$ day $^{-1}$ for female and $0.7 \mathrm{~kg}$ day $^{-1}$ for males. One can suggest that the performance of colostrum silage fed

Table 3 - Physical-chemical evaluation of anaerobically fermented colostrum.

\begin{tabular}{|c|c|c|c|c|c|c|c|}
\hline Fermentation Days & Protein $(\%)$ & Lactose $(\%)$ & $\mathrm{pH}$ & $\begin{array}{c}\text { DM (\%) } \\
\text { Média (SD) }\end{array}$ & Ash (\%) & LacticAcid(\%) & Fat $(\%)$ \\
\hline 0 & $14.4(5.1)$ & $2.3(0.5)$ & $6.5(0.1)$ & $22.4(4.9)$ & $2.2(1.1)$ & $4.9(1.1)$ & $6.1(0.7)$ \\
\hline 7 & $12.8(4.5)$ & $1.5(0.6)$ & $4.3(0.3)$ & $20.2(4.7)$ & $2.0(0.9)$ & $16.1(3.6)$ & $5.9(0.7)$ \\
\hline 14 & $13.1(4.8)$ & $1.1(0.7)$ & $4.2(0.3)$ & $17.3(3.7)$ & $2.4(0.9)$ & $19.5(6.6)$ & $5.6(0.7)$ \\
\hline 21 & $14.6(4.6)$ & $0.8(0.7)$ & $4.1(0.3)$ & $18.5(5.0)$ & $1.4(0.4)$ & $19.5(5.7)$ & $5.9(1.0)$ \\
\hline 30 & $13.4(3.9)$ & $0.76(0.6)$ & $4.0(0.2)$ & $16.5(3.4)$ & $1.6(0.5)$ & $21.1(5.9)$ & $5.8(1.0)$ \\
\hline 60 & $14.2(3.8)$ & ND (ND) & $4.0(0.2)$ & $17.5(4.9)$ & $1.7(0.6)$ & $28.7(4.8)$ & $5.5(1.0)$ \\
\hline
\end{tabular}

Ciência Rural, v.43, n.9, set, 2013. 
Table 4 - Average daily and cumulative weight gain (kg/day) of animals fed milk and colostrum silage.

\begin{tabular}{|c|c|c|c|c|}
\hline \multirow{2}{*}{ Parameters } & \multicolumn{4}{|c|}{ 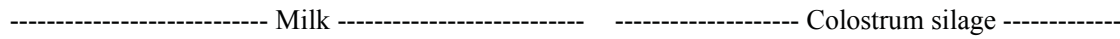 } \\
\hline & Female $(n=7)$ & Male $(n=10)$ & Female $(n=9)$ & Male $(n=5)$ \\
\hline Starting weight $(\mathrm{kg})$ & $33 \mathrm{a} \pm 5.1$ & $36 \mathrm{a} \pm 4.0$ & $38 \mathrm{a} \pm 2.7$ & $39 \mathrm{a} \pm 5.0$ \\
\hline Final Weight (kg) & $68 \mathrm{~b} \pm 5.8$ & $69 \mathrm{~b} \pm 5.3$ & $84 \mathrm{a} \pm 6.7$ & $84 \mathrm{a} \pm 11.6$ \\
\hline Cumulative weight gain (kg) & $34 \mathrm{~b} \pm 4.2$ & $32 \mathrm{~b} \pm 5.7$ & $46 \mathrm{a} \pm 5.7$ & $44 \mathrm{a} \pm 7.2$ \\
\hline Weight dairy (kg) & $0.6 \mathrm{~b} \pm 0.07$ & $0.6 \mathrm{~b} \pm 0.09$ & $0.7 \mathrm{a} \pm 0.09$ & $0.7 \mathrm{a} \pm 0.12$ \\
\hline
\end{tabular}

Different letters represent statistical difference between milk and colostrum silage.

animals is due to the higher percentage of nutrients retained in this feed. Also it is noteworthy to mention that they accepted the milk substitute (colostrum silage) with less restriction.

\section{CONCLUSION}

The results of this study show that colostrum silage is a suitable replacement for calves' milk. It is inexpensive, and easy to produce, store, and use, and it requires no additives or special equipment for its preparation. Thus, anaerobically fermented colostrum is a promising milk substitutes.

\section{ETHICS COMMITTEE AND BIOSAFETY}

The project was approved by the University Ethics Committee 23110.009613/2011-21 CEEA 9613

\section{ACKNOWLEDGEMENTS}

Thanks to dairy farmers in Southern Brazil, Center Training Farmers Canguçu RS - Centro de Ensino e Treinamento em Anatomia e Cirurgia Veterinária (CETAC) EMATER / RS and Empresa Brasileira de Pesquisa Agropecuária (EMBRAPA) station Lowland who collected silage colostrum and CETAC / EMATER / RS for the cession of the experimental animals.

\section{REFERENCES}

ALLEN, N.N. The use of stored colostrum to replace marketable milk for calf feeding. J Dairy Sci, v.27, p.652-653, 1944. Available from: $<$ http://download.journals.elsevierhealth. com/pdfs/journals/0022-0302/PIIS0022030244926391.pdf>. Accessed: Sept. 23, 2011

APPLEMAN, R.D.; OWEN, F.G. Breeding, housing, and feeding management. J Dairy Sci, v.58, p.447-464, 1975. Available from: $<$ http://download.journals.elsevierhealth.com/pdfs/journals/0022-0302/ PIIS0022030275845887.pdf?refuid $=$ S0022-0302(78)837199\&refissn=0022-0302\&mis=.pdf $>$. Accessed: Dec. 14, 2012. doi: 10.3168/jds.S0022-0302(75)84588-7.

BURITI, F.C.A.; SAAD, S.M.I. Bactérias do grupo Lactobacillus casei: caracterização,viabilidade como probióticos em alimentos e sua importância para a saúde humana. Arch Latinoam Nutr, v.57, p.373-380, 2007. Available from: $<$ http://www.scielo.org.ve/scielo. php?script $=$ sci_arttext\&pid=S0004-06222007000400010\&lng=es \&nrm=iso>. Accessed: Dec. 14, 2012

CAMPOS, O.F. et al. Colostro fermentado a temperatura ambiente, sem aditivos para bezerros leiteiros. Rev Soc Bras Zoot. v.15, p.338-349, 1986

DRACKLEY, J.K. Critical evaluation of feeding options for replacement calves. Adv Dairy Tech, v.11, p.152, 1999. Available from: $\quad<$ http://www.wcds.ca/proc/1999/Manuscripts/Chapt\%20 12\%20-\%20Drackley.pdf>. Accessed: May, 12, 2009.

FOLEY, J.A.; OTTERBY, D.E.J. Availability, storage, treatment composition, and feeding value of surplus colostrum: a review. J Dairy Sci, v.61, p.1033-1060, 1978. Available from: <http:/ www.sciencedirect.com/science/article/pii/S0022030278836868>. Accessed: May, 12, 2010. doi: 10.3168/jds.S0022-0302 (78) 83686-8.

GEORGIEV, I.P. Alterations in chemical composition of colostrum in relationship to post-partum time. Bulg J Vet Med., v.8, n.1, p.35-39, 2008. Available from: $<$ http://tru.uni-sz.bg/bjvm/vol11no1-01.pdf>. Accessed: Dec. 23, 2012.

GODDEN, S. Microbial risks associated with feeding colostrum to calves. Annu Mtg Southwest Nutrition and Management Conference, p.26-27, 2009. Available from: <http://www.cals. arizona.edu/ans/swnmc/Proceedings/2009/05Godden_09.pdf $>$. Accessed: Jan. 14, 2013.

HAGA, S. et al. Changes in hepatic key enzymes of dairy calves in early weaning production systems. J Dairy Sci, v.91, p.31563164, 2008. Avaliable from: <http://www.sciencedirect.com/ science/article/pii/S0022030208711111>. Accessed: Apr. 13, 2011. doi: $10.3168 /$ jds 2007-0853.

HEINRICHS, A.J.; HARGROVE, G.L. Standards of weight and height for Holstein heifers. J Dairy Sci, v.70, p.653-660, 1987. Available from: <http://www.journalofdairyscience.org/article/ S0022-0302(87)80055-3/abstract>. Accessed: Mar. 23, 2009 doi:10.3168/JDSS0022-0302(87)80055-3.

HIRSH, D.C.; ZEE,Y.C. Microbiologia veterinária. Rio de Janeiro: Guanabara-Koogan, 2003. 446p.

INSTITUTO ADOLFO LUTZ. Normas Analíticas do Instituto Adolfo Lutz: métodos químicos e físicos para análise de alimentos. São Paulo, 1985. 533p.

KEHOE, S.I. et al. A survey of bovine colostrum composition and colostrum management practices on Pennsylvania dairy farms J Dairy Sci, v.90, p.4108-4116, 2007. Available from: <http:// 
www.sulostrum.com/fileuploadmaster/161628_Research $\% 20$ Colostrum,\%20Kehoe\%202007.pdf>. Accessed: May, 10, 2010. doi: $10.3168 /$ jds.2007-0040.

LANUZA, F. et al. Variaciones en la composición química y microbiana del calostro acidificado a distintas temperaturas. In: REUNIÓN ANUAL DE LA SOCIEDAD CHILENA DE PRODUCCIÓN ANIMAL, IV, 1980, Valparaíso, Chile. Anais IV Reunión anual de la Sociedad Chilena de Producción animal, Valparaíso, Chile: Sociedad Chilena de Producción animal, 1980. p.45.

LUCCI, C. Bovinos leiteiros jovens. São Paulo: Nobel/Edusp, 1989. 371p.

NATIONAL. ANIMAL HEALTH MONITORING SYSTEM. Dairy herd management practices focusing on preweaned heifers. USDA: APHIS, 1993. Available from: < http://www. aphis.usda.gov/animal_health/nahms/dairy/downloads/ndhep/ NDHEP_HerdMgmt.pdf>. Accessed: May, 5, 2009.

NRC (NATIONAL RESEARCH COUNCIL). Nutrient requeriments of dairy cattle. 7.ed. Washington: National Academic, 2001. Available from: <http://www.nap.edu/openbook. php?isbn=0309069971 >. Accessed: June, 10, 2009.

SAALFELD, M.H. Uso da silagem de colostro como substituto do leite na alimentação. A Hora Veterinária, n.162, p.59-62, 2008.

STEWART, S. et al. Preventing bacterial contamination and proliferation during the harvest, storage, and feeding of fresh bovine colostrum. J Dairy Sci, v.88, p.2571-2578, 2005 Available in: <http://www.journalofdairyscience.org/article/ S0022-0302(05)72933-7/abstract>. Accessed: Sept. 10, 2009. doi: 10.3168/jds.S0022-0302 (05) 72933-7. 